\title{
Factors Influencing the Decision of Vietnamese Students to Study English in the Philippines
}

\author{
Van Dat TRAN 1 , Vu Linh Chi BUI ${ }^{2}$
}

Received: August 01, 2020 Revised: September 20, 2020 Accepted: October 05, 2020

\begin{abstract}
This paper aims to develop a conceptual framework for evaluating the impact of factors influencing the decision of Vietnamese students to study English in the Philippines. The empirical analysis used data from the survey data of 318 respondents living in Vietnam. Comprehensive, valid, and reliable tools (SPSS 26 software) are used to analyze and verify the gathered data, and the hypotheses developed. The results identified the factors that affect the decision of Vietnamese students to study English in the Philippines include knowledge and awareness, personality recommendation, cost issues, environment, geographic proximity, and social link. Based on the overall findings of this study, several implications are presented for educational practices in academies and schools about English teaching in the Philippines. To increase the ability to get students to study English in the country, it is important that schools or academies must understand the demands of students regarding the academic environment, and in particular, to know what factors determine the decision from the customers' point of view. This study contributes significantly to the understanding of agencies and educational managers about the student's choice behavior in the context of the need to improve foreign languages and, thus, help improve the competitiveness of agencies and English schools.
\end{abstract}

Keywords: Personality Recommendation, Cost Issues, Environment, Geographic Proximity

JEL Classification Code: M30, M31, M37

\section{Introduction}

In an era of globalization, English has become the most popular language in the world. Living in a developing country as Vietnam, Vietnamese believe that English is one of the key helping them integrate into the general development of mankind. So, studying English has become a trend in this country because of its necessity. In recent years, many citizens have chosen to study English abroad instead of at local language centers. Generally, there are

${ }^{1}$ First Author and Corresponding Author. Head, Marketing Department, Faculty of Business Administration, Banking University, Ho Chi Minh City, Vietnam [Postal Address: No.36, Ton That Dam Street, Nguyen Thai Binh Ward, District 1, Ho Chi Minh City, 710000, Vietnam] Email: dattv@buh.edu.vn

${ }^{2}$ Faculty of Business Administration, Banking University, Vietnam. Email: linhchinh179@gmail.com

(c) Copyright: The Author(s)

This is an Open Access article distributed under the terms of the Creative Commons Attribution Non-Commercial License (https://creativecommons.org/licenses/by-nc/4.0/) which permits unrestricted non-commercial use, distribution, and reproduction in any medium, provided the original work is properly cited. three countries for Vietnamese students to learn English within a reasonable distance: Singapore, Malaysia and the Philippines. One can also choose specialized English courses in universities in other countries with the convenience of the international environment to improve their language skills. However, in Vietnam, the number of companies providing consultant services to study English in the Philippines is growing. Established on September 9th, 2019, ASEP Vietnam, the Association for Studying English in the Philippines, has been developing with the participation of 11 members: ASCI - The Academic Service Cooperation International Co., Ltd; Eduphil - Edu Phil Study Abroad Consultant Co., Ltd; Filip English - Filip English Co., Ltd; Glolink - Glolink Co., Ltd; MICE - MICE Consulting Co., Ltd; Olympus - Olympus Global Co., Ltd; Phil English - Phil English Vietnam Co., Ltd; SS English Academy SS Edu Global Co,. Ltd; TriViet Edu - Tri Viet Education Communications Joint Stock Company; Hang Luong OSC; EduWin. According to statistics from Vietnamese managers in six schools in the Philippines, there are about 1,055 Vietnamese students who have taken part in courses there from 2018 to 2020. These is a good signal as a background to develop a new studying trend. 
Kuh and Kaufman (1984) have shown that international education enhances a student's ability to view world issues, independence, confidence, and optimism through cultural exchanges. Similarly, several reports explain the positive effects of increasing flexibility, adaptability, self-reliance, flexibility, and straightforwardness as well (Nash, 1976). Carlson et at. (1990) also found similar results when studying 204 international students and 153 domestic students. The author designed a survey to assess students' interest in culture and world events. The results showed that international students are more interested in global events as well as more culturally aware. The study also points out that the interaction between international students and native speakers is a great opportunity for international students to learn more about the culture. Several other studies also suggest that studying abroad is not only for language studies, but also for the many benefits students derived from a global education programs (Cushner \& Mahon, 2002).

There are many ways to improve one's language besides studying in local language centers, E - learning, participating in English club, etc. Nowadays, traveling between countries is easier and more convenient via modern transportations. Thus, people choose to study English in English-speaking nations like Singapore, Malaysia, Australia, and especially the Philippines. What are the reasons leading to Vietnamese students' decision to improve their English in the Philippines is the research subject of this study. This research analyzes the impact of factors to the decision of Vietnamese students to study English in the Philippines. Thus, the research scope focuses on identifying factors and their influence in the period from 2018 to 2020 .

This research has three main objectives: (1) to find out the factors influencing the decision of Vietnamese students to study English in the Philippines; (2) to measure the impact of factors on the decision of Vietnamese students to study English in the Philippines; and (3) to make recommendations to the management.

Most of the previous research done about the decision to study abroad are generic, without focusing on specific country or specialization. Therefore, we would like to conduct this research about 'Factors influencing the decisions of Vietnamese students to study English in the Philippines' to contribute new information to this field of research. The results are trustworthy information for agencies in Vietnam and English schools in the Philippines to build reasonable, suitable strategies for their businesses.

\section{Literature Review and Hypotheses}

\subsection{Theory of Reasoned Action (TRA)}

Theory of Reasoned Action(TRA) was formulated in 1967. During the early 70 s, this theory was expanded by Ajzen and Fishbein. Since 1980, it has been used in research regarding human behavior to come up with appropriately solutions to address problems. In 1988, to address the limitations of the TRA model, Ajzen and Fishbein (1970) introduced the Behavior control awareness variable to develop the Theory of Planned Behavior (TPB). The development of TRA and TPB was originally developed from the psychosocial field. Since 1862, psychologists have begun to develop theories that explain how attitude affects behavior. From 1918 to 1925, they continued to research the correlation between attitude and behavior. It was also the time when many new hypotheses appeared that emphasized the effects of attitude on the formation of behavior, which has since dominated the 20th century scholarship.

Ajzen and Fishbein (1970) thought that attitude can explain the actions of humans. Doob (1947) agreed with Thurstone who thought that attitude does not influence directly behavior, but attitude shows the overview of behavior to which individual can react. Rosenberg and Hovland (1960) hypothesized that a person's attitude toward an object is determined by their influence, perception and behavior. Wicker and Pomazal (1970) carried out a survey and considered the previous studies again. The conclusion showed that there are many possibilities that attitude does have few or no relationship to behavior (Ajzen \& Fishbein, 1980). Based on the results, Ajzen and Fishbein (1980) focused on researching how to predict behavior and resulting action. They thought that individuals are rational and often use the available information around them. People consider the results of actions before they make decision - whether or not to engage in a certain behavior. After considering all the studies, Ajzen and Fishbein (1980) developed a theory that can understand and predict the behavior and attitude of individuals. Nowadays, this theory is known as the Theory of Reasoned Action, which reflects the need to consider the behavioral tendency rather than attitude as an predictive indicator.

\subsection{Hypothesis development}

Eder et al. (2010) identified factors influencing the choice of students' study destination abroad; the researchers built a model based on Mazzarol and Soutar (2002) regarding international students' destination decision. The model includes three main factors: push factor, pull factor, and structural factor. There are three elements in the push factor: personal growth, language, and career. Pull factor includes college issues, physical geography, and culture. Structural factor has two elements: visa issues and monetary issues. Tran (2020) demonstrated that all of the above factors have influence on the destination choice of student. His findings confirm that service quality influences experience values, relationship quality and purchase intention. Service quality, experience value, relationship quality, and behavior intentions altogether are not well understood in the current 
literature despite the important implication for managers, academicians and consumers alike.

Trisnaningsih et al. (2020) suggested that the Diploma Supplement and networking can increase the uptake of higher education graduates in Indonesia as expected by stakeholders and be able to compete in the global or international scale of environmental working. The professionalism of lecturers has a significant influence on the quality of learning. The research by Booker (2001) has explored the difference between applicants and non-applicants who study abroad looking at the comparison of personal characteristics, interest in studying abroad, and awareness of organizations supporting international education. Booker also examined about social pressure and the awareness of obstacles in students' intention. This research is based on the theory of reasoned action and the theory of planned behavior to show the factors influencing the intention of studying abroad: hobbies, information seeking, reviews, behavioral intention, program selection, and application. The personal knowledge background of student, experience and others' idea, alternative choice, opportunities and related information were also considered in the model.

Teichler (2004) provided explanations of the benefits that students gain when studying abroad. Firstly, learning is to cultivate knowledge. Second, international education and research bring multicultural knowledge including sociocultural, educational, economic, and about political systems. All of these experiences contribute to personal growth so that after graduation students can immediately enter the labor market. In addition, students can be aware of world issues through learning. Students perceive these benefits from exchanging information through international education. At the University of California, Wilson and Barber (1983) presented their results showing that international students have strong arguments and positive thinking about things happening in the United States and the countries where they were studying.

H1: Knowledge and awareness of Vietnamese students have a positive influence on decision to study English in the Philippines

Studying abroad has been considered as the process of acquiring necessary language skills, but nowadays studying abroad is increasingly used as an effective way to build global competitiveness and awareness for learners. Studying abroad is a form of education for capacity building for students by providing necessarily social skills as well as improving confidence to pursue a career path in the context of international integration. Kuh and Kauffman (1984) researched the change in self-esteem, the confidence of students before and after studying abroad. The study selected 126 international students and 90 students from different schools in the country. The results showed that international students showed a more positive change in their self-esteem and self-confidence than domestic students and they also increased their concern about issues that are happening around them. Mahbubur Rahman et al., (2020) provided an insight about students' satisfaction that might be useful to authorities of public universities and other higher educational institutions in designing policies for various services and facilities offered to their students. In addition, Mazzarol and Souter (2002) found five dimensions about "push-pull" factors influencing international student destination choice: knowledge and awareness, personal recommendations, cost issues, geographic proximity, and social links.

H2: Personal recommendations have a positive influence on decision of Vietnamese students to study English in the Philippines.

H3: Cost issues have a positive influence on decision of Vietnamese students to study English in the Philippines.

Kuh and Kauffman (1984) have shown that international education enhances a student's ability to view world issues, independence, confidence, and optimism through cultural exchanges. Similarly, several reports explain the positive effects of increasing flexibility, adaptability, self-reliance, and straightforwardness as well (Nash, 1976). Juhasz and Walker (1987) suggest that international students studying abroad significantly improve their productivity and know-how to take care of themselves. In this study, the author selected 70 students studying in Italy, and compared the changes of each individual before and after studying abroad. The results show that there is a significant change in the way these international students manage work, time, and the self-care skills. The students who have studied above skills the longest achieved more than students with a shorter curriculum. In a quantitative study of students from Goshen College, Kauffman (1992) showed positive growth in students studying in an international educational environment. Both of these studies have shown the same results: the learning process in a foreign environment helps students develop an awareness of cultural differences leading to the process of identifying themselves more clearly and have changes in behavior and personality.

H4: Environment has a positive influence on decision of Vietnamese students to study English in the Philippines.

In a study of 52 students in Santiago (Chile), Stephenson (1999) requested students to complete a questionnaire before and after studying abroad. Questions measured cultural awareness. Through descriptive statistics, Stephenson asserted that the perception of international students about the United States remains unchanged, but there is a change in awareness of other cultures. According to Mazzarol and Soutar (2002) the first factor showed "the level of knowledge and awareness" of students about the host country, which influences student's decision based on the information they 
collected. The recognition in the student's hometown and educational quality is also mentioned in this factor. Secondly, personal recommendations factor explains whether or not the advice from important people as parents, friends, and teachers have influence on the choice of students. Thirdly, there are cost issues including travel costs, living expenses, tuition fees, social cost to be safe in society, and rate of discrimination. The next factor is environment involving the impact from climate and lifestyle of the host country. Geographic proximity is a factor related to the time and geographic proximity of the country where student would like to study. The final factor are the social links that would affect student's decision and which depends on having relatives or friends who used to study there.

H5: Geographic proximity has a positive influence on decision of Vietnamese students to study English in the Philippines.

H6: Social links have a positive influence on decision of Vietnamese students to study English in the Philippines.

\section{Research Methodology}

\subsection{Research Framework}

The decision to study abroad involves a group of factors leading to the choice of destination or institution. The majority of decisions are considered carefully because of the trade-off between time and finance. Researching the impacts on the destination choice of international students, Mazzarol and Soutar (2002) focused on six factors: knowledge and awareness, personal recommendations, cost issues, environment, geographic proximity, and social links. Inheriting aspects in the above-mentioned research models about factors influencing the decision to study abroad, the model in this study is primarily referenced in the study by Mazzarol and Soutar (2002). As presented in Figure 1, the variables include knowledge and awareness, personal recommendations, cost issues, environment, geographic proximity, and social links, which are reasonable with this topic. In this study, the author proposed a research model as follows (see Figure 1):

\subsection{Measurement Scale}

The outcome of above model plays an important role as the theoretical basis of the following studies. The impact of five factors, including knowledge and awareness, personal recommendations, cost issues, geographic proximity, and social links are also identified by Eder et al. (2010). Similarly, the study about choosing a higher education destination to study abroad (Bodycott, 2009) showed results with four of the six factors listed by Mazzarol and Soutar. Besides, several other studies document the existence of the impact of both cost issues (Pimpa, 2003; Lee, 2007; Li, 2015; Eder et al., 2010) and environment (Gatfield \& Hyde, 2005; Yang, 2007; Chung et al, 2009). See Table 1.

\subsection{Sample and Data Collection}

\subsubsection{Sample size}

The EFA analysis method requires a sample size, which must be at least 4-5 times the number of variables. This study is measured by 42 observed variables, so the sample size is $42 * 5=210$. To ensure representative, logic, correctness and minimization of errors in the process to take convenient samples, this study will be based on over 250 samples.

The target audience is Vietnamese students who have studied or are currently studying English in the Philippines

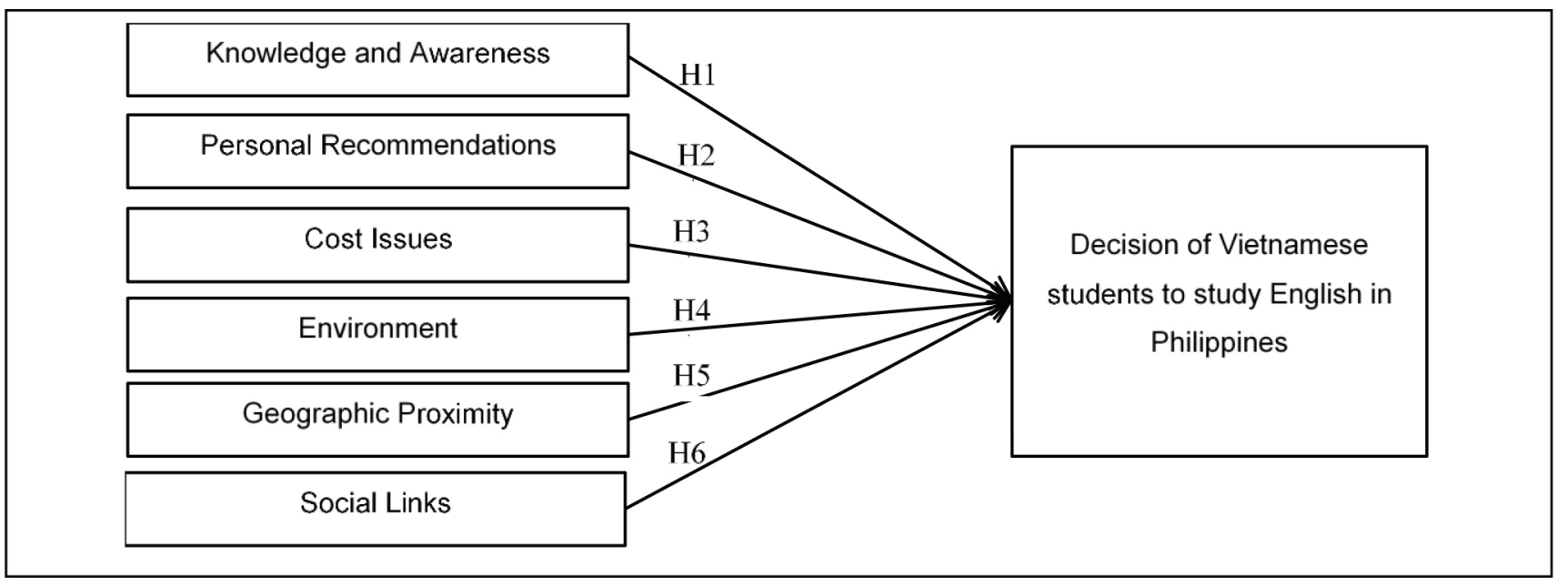

Figure 1: Research framework 
Table 1: Indicators of Scales

\begin{tabular}{|c|c|c|}
\hline Coded & Measurement Items & References \\
\hline \multicolumn{2}{|c|}{ KNOWLEDGE AND AWARENESS } & \multirow{14}{*}{$\begin{array}{l}\text { Mazzarol \& Soutar } \\
2002 \\
\text { Body Cott, 2009; } \\
\text { Chung, et al., 2009 }\end{array}$} \\
\hline KA1 & $\begin{array}{l}\text { I gain information on the educational quality of English major in schools in } \\
\text { Philippines easily }\end{array}$ & \\
\hline KA2 & $\begin{array}{l}\text { The fair/ seminar/ exhibition about studying abroad provides for me full of } \\
\text { information of Philippines and English schools }\end{array}$ & \\
\hline KA3 & $\begin{array}{l}\text { The source of information from friend or relative has a great influence on my } \\
\text { decision to study English in Philippines }\end{array}$ & \\
\hline KA4 & $\begin{array}{l}\text { The source of information on the Internet has a great influence on my decision to } \\
\text { study English in Philippines }\end{array}$ & \\
\hline KA5 & $\begin{array}{l}\text { The source of information from newspaper advertisings has a great influence on } \\
\text { my decision to study English in Philippines }\end{array}$ & \\
\hline KA6 & $\begin{array}{l}\text { The source of information from internationally educational magazines has a great } \\
\text { influence on my decision to study English in Philippines }\end{array}$ & \\
\hline KA7 & $\begin{array}{l}\text { The source of information from television advertisings has a great influence on } \\
\text { my decision to study English in Philippines }\end{array}$ & \\
\hline KA8 & $\begin{array}{l}\text { The source of information from the agents of Philippines English schools in } \\
\text { Vietnam has a great influence on my decision to study English in Philippines }\end{array}$ & \\
\hline KA9 & Vietnam does not have enough the supply of English schools as Philippines & \\
\hline KA10 & English education in Vietnam does not have high quality & \\
\hline KA11 & $\begin{array}{l}\text { I have opportunities to learn and exchange more and more regarding the culture } \\
\text { of other countries within the time I study English in Philippines }\end{array}$ & \\
\hline KA12 & $\begin{array}{l}\text { Studying English in English - speaking as Philippines can help me improve } \\
\text { communication skill quickly }\end{array}$ & \\
\hline KA13 & $\begin{array}{l}\text { Certificate from English - speaking as Philippines have more value than one } \\
\text { from Vietnam }\end{array}$ & \\
\hline \multicolumn{3}{|c|}{ PERSONAL RECOMMENDATIONS } \\
\hline PR1 & My parents have a great influence on my decision to study English in Philippines & \multirow{7}{*}{$\begin{array}{l}\text { Mazzarol \& Soutar, } \\
2002 \\
\text { Body Cott, 2009; } \\
\text { Chung, et al., 2009 }\end{array}$} \\
\hline PR2 & $\begin{array}{l}\text { Other members in my family have a great influence on my decision to study } \\
\text { English in Philippines }\end{array}$ & \\
\hline PR3 & $\begin{array}{l}\text { Agents recommendation has a great influence on my decision to study English in } \\
\text { Philippines }\end{array}$ & \\
\hline PR4 & The reputation of English schools in Philippines have an affect on my decision & \\
\hline PR5 & $\begin{array}{l}\text { The advice of teacher(s) (excluding Filipino) have a influence on my decision to } \\
\text { study English in Philippines }\end{array}$ & \\
\hline PR6 & $\begin{array}{l}\text { My friend(s)'s opinions have a influence on my decision to study English in } \\
\text { Philippines }\end{array}$ & \\
\hline PR7 & $\begin{array}{l}\text { Reviews and shares from alumni have a influence on my decision to study } \\
\text { English in Philippines }\end{array}$ & \\
\hline
\end{tabular}


Table 1: Continued

\begin{tabular}{|c|c|c|}
\hline \multicolumn{3}{|c|}{ COST ISSUES } \\
\hline $\mathrm{Cl} 1$ & $\begin{array}{l}\text { Tuition fee (including tuition fee, dormitory fee and main meals) to study English } \\
\text { in Philippines is lower than it to study English in other countries }\end{array}$ & \multirow{9}{*}{$\begin{array}{l}\text { Mazzarol \& Soutar } \\
\text { 2002; Body Cott, 2009 } \\
\text { Chen \& Zimitat, } 2006\end{array}$} \\
\hline $\mathrm{Cl} 2$ & $\begin{array}{l}\text { Living cost (including local fees and individual fees) to study English in } \\
\text { Philippines is lower than it to study English in other countries }\end{array}$ & \\
\hline $\mathrm{Cl} 3$ & $\begin{array}{l}\text { Travel cost to study English in Philippines is lower than it to study English in } \\
\text { other countries }\end{array}$ & \\
\hline $\mathrm{Cl} 4$ & The quantity of international students in Philippines is high & \\
\hline $\mathrm{Cl} 5$ & Entry qualifications of students are accepted in schools in Philippines & \\
\hline $\mathrm{Cl} 6$ & Philippines has a safe social order with low crime rate & \\
\hline $\mathrm{Cl} 7$ & The radical discrimination in Philippines is low & \\
\hline $\mathrm{Cl} 8$ & Career opportunities is increased after finishing English course(s) in Philippines & \\
\hline $\mathrm{Cl9}$ & $\begin{array}{l}\text { Course duration has a great influence on my decision to study English in } \\
\text { Philippines }\end{array}$ & \\
\hline \multicolumn{3}{|c|}{ ENVIRONMENT } \\
\hline EN1 & The climate in Philippines where I study is comfortable & \multirow{8}{*}{$\begin{array}{l}\text { Chung, et al., 2009; } \\
\text { Chen \& Zimitat, 2006; } \\
\text { Body Cott, } 2009\end{array}$} \\
\hline EN2 & Philippines is a exciting place to live & \\
\hline EN3 & Studying environment in Philippines is quiet & \\
\hline EN4 & An orderly society as Philippines is important to me & \\
\hline EN5 & My schoolmates in Philippines are ambitious to get proficiency in English & \\
\hline EN6 & Having a good time is important to me to study English & \\
\hline EN7 & $\begin{array}{l}\text { I have opportunities to learn and exchange in multicultural environment within the } \\
\text { time I study English in Philippines }\end{array}$ & \\
\hline EN8 & The lifestyle of Philippines is similar as mine & \\
\hline \multicolumn{3}{|c|}{ GEOGRAPHIC PROXIMITY } \\
\hline GR1 & $\begin{array}{l}\text { In my mind, the geographical distance between Vietnam and Philippines is } \\
\text { nearer than it between Vietnam and other English - speaking countries }\end{array}$ & \multirow{3}{*}{$\begin{array}{l}\text { Mazzarol \& Soutar } \\
\text { 2002; } \\
\text { Body Cott, 2009; } \\
\text { Soo \& Elliott, 2008 }\end{array}$} \\
\hline GR2 & $\begin{array}{l}\text { In my mind, the geographical distance between Vietnam and the city I study in } \\
\text { Philippines is near }\end{array}$ & \\
\hline GR3 & Supporting onsite accommodation to international students is necessary & \\
\hline \multicolumn{3}{|c|}{ SOCIAL LINK } \\
\hline SL1 & I have friends and relatives having studied in Philippines & \multirow{2}{*}{$\begin{array}{l}\text { Mazzarol \& Soutar } \\
2002\end{array}$} \\
\hline SL2 & I have friends and relatives having lived in Philippines & \\
\hline
\end{tabular}


continuously from 1 to 6 months or more. Therefore, the criterion is those students who decided to study English in the Philippines.

\subsubsection{Questionnaire design}

The questionnaire is designed in three ways: (i) use of the original scale from previous studies; (ii) the same, but with adjustment to be suitable for the study objects; (iii) design and development of a completely new scale (Creswell, 2003). The author applies the second way to design scales for this study. The research questionnaire is based on the study by Mazzarol and Soutar (2002) and adjusted to suit the study object. Respondents answer questions related to knowledge and awareness, personal recommendation, cost issues, environment, geographic proximity, and social links. Also, age, gender, job, marital status, permanent place, education, and income are included. In this study, this independent variables are measured by a 7-point Likert scale, from 1 'Strongly disagree' to 7 'Strongly agree'. In this section, each independent variable has several questions.

\subsubsection{Data collection method}

The research subjects are students who have been learning English in the Philippines. The data was collected from January 2020 to August 2020. This study uses only one method of collecting sample, online survey due to the convenience of information technology, time, geographic proximity and the limitations of COVID-19 pandemic. Taking advantage of working with the Association for Studying English in the Philippines (ASEP) and the help of agencies in Ho Chi Minh City and Hanoi City, the author sent the surveys through Google form to students.

\section{Results and Discussion}

\subsection{Reliability Analysis}

A total of 318 samples were collected. Of these, 23 questionnaires were invalid because respondents omitted answers. Therefore, 295 samples were analyzed quantitatively with SPSS 20 software.

\subsection{Reliability of Scale}

Cronbach's Alpha coefficient provides an indication of the average correlation between all items that make up the scale. In order for Cronbach's alpha to be valid, the following criteria are required: testing the reliability of the scale through Cronbach's Alpha coefficient and the scale is accepted if the coefficient is greater than 0.7 (Nunnally, 1978; Hair, 2010). Elimination of observed variables have Item-Total correlation
Table 2: Respondent Profile

\begin{tabular}{|c|c|c|}
\hline Category & $\begin{array}{l}\text { Number of } \\
\text { respondents }\end{array}$ & Percentage \\
\hline \multicolumn{3}{|l|}{ Gender } \\
\hline Male & 107 & $37 \%$ \\
\hline Female & 185 & $63 \%$ \\
\hline \multicolumn{3}{|l|}{ Age } \\
\hline Less than 18 years old & 67 & $23 \%$ \\
\hline $18-22$ years old & 129 & $41 \%$ \\
\hline 23-30 years old & 102 & $25 \%$ \\
\hline $31-40$ years old & 3 & $1 \%$ \\
\hline \multicolumn{3}{|l|}{ Occupation } \\
\hline Student & 130 & $44 \%$ \\
\hline Manufacturing & 15 & $5 \%$ \\
\hline Housekeeping & 14 & $5 \%$ \\
\hline Retail/ Distribution & 12 & $4 \%$ \\
\hline $\begin{array}{l}\text { Banking/ Financial/ } \\
\text { Insurance }\end{array}$ & 28 & $10 \%$ \\
\hline Government & 22 & $7 \%$ \\
\hline Media/ Publishing & 29 & $10 \%$ \\
\hline Others & 45 & $15 \%$ \\
\hline \multicolumn{3}{|l|}{ Education } \\
\hline $\begin{array}{l}\text { Senior High Diploma or } \\
\text { Below }\end{array}$ & 59 & $20 \%$ \\
\hline Associate Bachelor Degree & 33 & $11 \%$ \\
\hline Bachelor Degree & 196 & $67 \%$ \\
\hline Master Degree & 4 & $2 \%$ \\
\hline
\end{tabular}

of less than 0.4 (Nurosis, 1994): knowledge and awareness $=0.956$, personality recommendation $=0.900$, cost issues $=$ 0.925 , environment $=0.906$, geographic proximity $=0.857$, social link $=0.724$, decision to study English in Philippines $=0.811$. The results show Cronbach's Alpha coefficient $>0.7$ and the Corrected Item-Total Correlation $>0.4$. Therefore, the scale of subjective variables is reliable.

\subsection{EFA Factor Analysis}

Exploratory factor analysis (EFA) helps examine the convergent value and discriminant value. EFA must satisfy the following requirements: factor loading $>0.5 ; \mathrm{KMO} \leq$ $0.5 \leq 1$; Bartlett test the statistical significance (Sig. $<0.05$ ); percentage of variance in Extraction Sums of Squared Loadings $>50 \%$.

The results of factor analysis show that the KMO index is $0.946>0.5$, which proves that the data used for factor 
analysis is perfectly appropriate. Bartlett's test result is 861 with Sig $=0.000<0.05$. Therefore, the hypothesis $\mathrm{H} 0$ is rejected; the observed variables have no correlation with each other in the whole. So, variables are correlated with each other and satisfy factor analysis conditions. In addition, the results showed that 42 observed variables were grouped into six groups. The value of the total variance extracted $=65,915$ $>50 \%$, which is satisfactory; then it can be said that these six factors explain $65,915 \%$ of the data variability. Finally, factor loadings are greater than 0.5 , and there is no case in which the upload of both factors at the same time has a close load factor. So, factors ensure convergence and differentiation when analyzing EFA. In addition, there is no disturbance of factors, meaning that one question cannot be confused with another. Therefore, after factor analysis, these independent factors remain the same, without being added or reduced.

\subsection{Correlation Analysis}

Pearson correlation analysis results show that several independent variables are correlated with each other. Therefore, the regression analysis should pay attention to the problem of multi-collinearity. The independent variables are correlated with the dependent variables and therefore will be included in the model to explain the dependent variables. The results showed that the strongest correlation is between DS (Decision to study English in Philippines) and EN (Environment) well-being: $\mathrm{r}=0.691>0$. It is based on $\mathrm{N}=$ 292 and sig $=0.000$. Therefore, DS and EN have a positive correlation $(r>0)$. The second significant correlations in the table are 0.618 , which represents DS (Decision to study English in the Philippines) and GR (Geographic proximity).

\subsection{Multiple Linear Regression Analysis}

Linear regression is a function that allows an analyst or statistician to make predictions about one variable based on information known about another. The formula for multiple linear regression is:

$$
\mathrm{Yi}=\beta 0+\beta \neg 1 \mathrm{xi} 1+\beta \neg 2 \mathrm{xi} 2+\ldots+\beta \neg \text { pxip }+\epsilon
$$

where, for $\mathrm{i}=n$ observations: Yi: dependent variable; $\mathrm{Xi}$ : explanatory variables; $\beta 0: \mathrm{y}-$ intercept (constant term); $\beta \neg p$ : slope coefficients for each explanatory variable, $\epsilon$ : the model's error term (also known as the residuals)

The coefficient of determination (R-squared) is a statistical metric that is used to measure how much of the variation in outcome can be explained by the variation in the independent variables. R2 always increases as more predictors are added to the multiple linear regression model even though the predictors may not be related to the outcome variable.

R2 by itself cannot, thus, be used to identify which predictors should be included in a model and which should be excluded. R2 can only be between 0 and 1, where 0 indicates that the outcome cannot be predicted by any of the independent variables and 1 indicates that the outcome can be predicted without error from the independent variables (see Table 3).

Adjusted R-square shows $59.9 \%$ of the complete variance of the dependent variable (Decision to study English in the Philippines) that can be interpreted by six independent factors (knowledge and awareness, personality recommendation, cost issues, environment, geographic proximity, social link). The remaining $40.1 \%$ are due to factors outside the model and random errors. Moreover, the result showed that ANOVA refers to the applied regression model's statistical significance. For the sig $=0.000<0.005$, the result offers evidence that the model used is suitable for forecasting the outcome (see Table 4).

Table 3: Respondent Profile

\begin{tabular}{|l|c|c|c|c|}
\hline Model & $\mathbf{R}$ & $\begin{array}{c}\mathbf{R} \\
\text { Square }\end{array}$ & $\begin{array}{c}\text { Adjusted R } \\
\text { Square }\end{array}$ & $\begin{array}{c}\text { Std. Error } \\
\text { of the } \\
\text { Estimate }\end{array}$ \\
\hline 1 & $.779^{\mathrm{a}}$ & .607 & .599 & .53145 \\
\hline \multicolumn{4}{|l}{ a. Predictors: (Constant), SL, PR, KA, Cl, GR, EN } \\
\hline
\end{tabular}

Table 4: Coefficients

\begin{tabular}{|c|c|c|c|c|c|c|}
\hline \multirow{2}{*}{ Model } & & \multicolumn{2}{|c|}{ Unstandardized Coefficients } & \multirow{2}{*}{$\begin{array}{c}\text { Standardized Coefficients } \\
\text { Beta }\end{array}$} & \multirow{2}{*}{$\mathbf{t}$} & \multirow{2}{*}{ Sig. } \\
\hline & & B & Std. Error & & & \\
\hline \multirow{7}{*}{1} & (Constant) & .466 & .251 & & 1.860 & .064 \\
\hline & $\mathrm{KA}$ & .102 & .040 & .118 & 2.552 & .011 \\
\hline & PR & .117 & .036 & .141 & 3.285 & .001 \\
\hline & $\mathrm{Cl}$ & .104 & .043 & .120 & 2.430 & .016 \\
\hline & EN & .313 & .057 & .304 & 5.498 & .000 \\
\hline & GR & .180 & .043 & .206 & 4.163 & .000 \\
\hline & $\mathrm{SL}$ & .112 & .043 & .126 & 2.635 & .009 \\
\hline
\end{tabular}




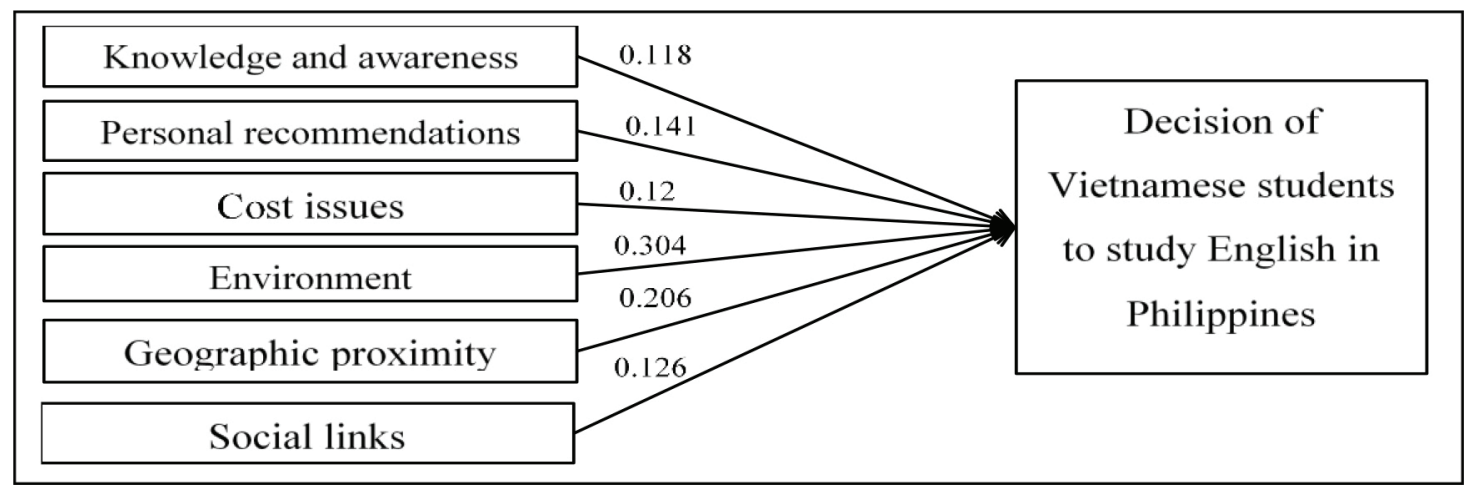

Figure 2: Model Tests

- Beta coefficient of KA variable is 0.102 with accreditation $\mathrm{t}=2.552$, sig $=0.011<0.05$.

KA variable is statically significant.

- Beta coefficient of PR variable is 0.117 with accreditation $\mathrm{t}=3.285$, $\mathrm{sig}=0.001<0.05$.

PR variable is statically significant.

- Beta coefficient of CI variable is 0.104 with accreditation $\mathrm{t}=2.430$, sig $=0.016<0.05$.

CI variable is statically significant.

- Beta coefficient of EN variable is 0.313 with accreditation $\mathrm{t}=5.498$, sig $=0.000<0.05$.

$\mathrm{EN}$ variable is statically significant.

- Beta coefficient of GR variable is 0.180 with accreditation $\mathrm{t}=4.163$, sig $=0.000<0.05$.

GR variable is statically significant.

- Beta coefficient of SL variable is 0.112 with accreditation $\mathrm{t}=2.635$, sig $=0.009<0.05$.

SL variable is statically significant.

The standardized regression model is as follows:

$$
\begin{aligned}
\mathrm{DS} & =0.118 \mathrm{KA}+0.141 \mathrm{PR}+0.12 \mathrm{CI}+0.304 \mathrm{EN} \\
& +0.206 \mathrm{GR}+0.126 \mathrm{SL}
\end{aligned}
$$

Because all the sig coefficients are smaller than 0.05 , all the other variables including knowledge and awareness, personality recommendation, cost issues, environment, geographic proximity, and social link are accepted and all of them have a positive effect on the decision to study English in the Philippines. The last model of this study is described below (Figure 2):

\section{Discussion}

Because studying English in the Philippines is a new field in Vietnam and no previous studies had been conducted, the purpose of this study is to identify and test factors that influence Vietnamese students' decisions. Vietnamese students are choosing to learn English, thus, providing the basis for the study of decision behavior. So, the research has fulfilled its objectives.

The study was based on the research model by Mazzarol and Soutar (2002). Previous studies showed that all six factors mentioned were significant in influencing the decision to study abroad; these are also the results of this study: knowledge and awareness (0.118), personality recommendation $(0.141)$, cost issues $(0.12)$, environment (0.304), geographic proximity $(0.206)$, and social link (0.126). The model only explained $59.9 \%$. This may stem from differences in the research context as well as the subjects of the survey, so more testing is needed.

\section{Conclusions}

The study identified factors that affect the decision of Vietnamese students to study English in the Philippines. They include knowledge and awareness, personality recommendation, cost issues, environment, geographic proximity, and social link. The two factors that have the most influence on this decision are environment (0.304) and geographic proximity $(0.206)$, which show that these factors are especially relevant in deciding where to study English. In addition, personality recommendation (0.141), social link (0.126), cost issues (0.12), and knowledge and awareness (0.118) are also important determinants of review credibility. Besides, the explanatory power of the model is not high at only $59.9 \%$. The cause for this may stem from the problem of research data or because the research model has many points that are not suitable for the research environment and context.

\subsection{Managerial Implications}

Based on the overall findings of this study, several implications are presented for educational practices in academies and schools about English in the Philippines. To increase the ability to get students to study English in the 
Philippines, it is important that schools or academies must understand the demands of students regarding an academic environment, and in particular, to know what factors determine the decision from the customers' point of view. These studentoriented insights are of particular importance to educational organizations with strong market orientation and customer focus in the context of popular demand to improve language learning. To begin with, managers should consider the importance of environmental factors, in particular, learning and exchange in a multicultural context. For instance, managers could offer students to write their feelings, requirements, and recommendations after each of the study weeks about the environment they want to be in. Managers should arrange Vietnamese students to live with Taiwanese, Chinese, Korean, Japanese, or Thais together in a dormitory, which helps them with more opportunities to communicate and improve English skills or other languages. Other elements as quiescence, an orderly society, the personality time of students, or lifestyle in schools should be maintained.

Secondly, schools in the Philippines and agencies in Vietnam should focus on proposing the government to allow direct flights from Vietnam to Mactan airport, Cebu province, where the majority of Vietnamese students choose to study, in order to shorten travel time. The importance of geographic distance is not only between the two countries, but also between the place of residence and place of learning of students in the Philippines. It is important for schools to build dormitories on campus or buildings where students study.

Personality recommendations are evaluated as the third most important factor affecting the decision of Vietnamese students to study English in the Philippines. Agencies need to promote the benefits of learning English in the Philippines to parents and teachers. At the same time, schools should collect suggestions, recommendations, and wishes of alumni after they have finished the courses and share that on the website or fan page where potential students could consult information when needed. Moreover, in order to attract students to study at schools, the schools need to actively improve their reputation on the rankings. Although social link is not directly impacted by schools and agencies, this factor can still be influential by offering a variety of promotions as well as after-school benefits for students. For example, students who are referred by alumni who studied at the school or have a relative who studied at the school and is currently living in the Philippines will receive a $10 \%$ discount on tuition fee and accommodation. In addition, the certifications of English schools in the Philippines are very useful for students because it is valid all over the world, especially in large countries like the US, UK, Australia, and others.

Opportunity costs (non-financial costs) in terms of the number of international students, the recognition of entry qualifications of international organizations, safe social order, radical discrimination, or career opportunities are more focused in the perspective of students choosing to study English in the Philippines. Besides attraction by promotion, schools should cooperate with international organizations as universities and firms in other countries to give the opportunity for students to transfer certificate as a official English certificate when they want to study abroad in the future. Lastly, knowledge and awareness is also mentioned as a important factor influencing the decision of Vietnamese students. By updating information of Filipino English Schools on fan page and websites, agencies and educational managers can provide references to students when they have a demand to study English.

Overall, it can be said that the understanding of the factors leading to Vietnamese students' decision to study English in the Philippines and the extent of their impact is very important for research and enrollment activities because they contributes greatly to the understanding of agencies and educational managers about the student's choice behavior in the context of the need to improve foreign languages and, thus, help improve the competitiveness of agencies and English schools.

\subsection{Limitations}

The research has limitations. The process of collecting sample data is very difficult because of the questionnaire interview in which the truthfulness of the data depends on honesty, the ability to understand, and the attitude of the respondents. In addition, after collecting the questionnaires, the research data is still in raw form that needs to be processed and inputted into the software, so the search and collation take time and lead inevitably to errors. The research sample included 292 students who had time to study at Filipino English schools. Although the author has tried to increase the sample size, it is still not possible to cover all students who have studied abroad in this form due to time and space limitations. Besides, the actual working context was impacted by the COVID-19 epidemic, which placed constraints to study abroad. The research results are therefore not highly generalized. However, they show that the $\mathrm{R} 2$ coefficient in the regression model explain $59.90 \%$ of the degree of variation, so that although the sample size has not covered the whole population, the factors explained over $50 \%$ of the decision of Vietnamese students to study English in the Philippines.

\subsection{Future Research}

Although the research has certain limitations, it has achieved its objectives coming up with the results obtained with statistical significance and in line with the results of studies elsewhere in the world. Future studies should collect data on a larger scale to cover all Vietnamese students who have studied English in the Philippines; the results will be 
more reliable. More time and financial resources should be invested to be able to study the influence of factors on the intention of studying abroad for high school students in a longer period. The results obtained from studies on this issue will be more generalizable. Because the independent variables in the research model only explain $59.90 \%$ of the degree of variation in the decision, there are still other independent variables that explain the intention of studying abroad for high school students. As such, further studies can expand the number of independent variables.

\section{References}

Ajzen, I., \& Fishbein, M. (1970). The prediction of behavior from attitudinal and normative variables. Journal of Experimental Social Psychology, 6(4), 466-487.

Bodycott, P. (2009). Choosing a higher education study abroad destination: What Mainland Chinese parents and students rate as important. Journal of Research in International Education, 8, 349-373.

Booker, R., (2001). Differences between applicants and nonapplicants relevant to the decision to apply to study abroad. University of Missouri-Columbia.

Carlson, J. S., Burn, B. B., Useem, J., \& Yachimowicz, D. (1990). Study abroad: The experience of American undergraduates. New York, NY: Greenwood.

Chen, C., \& Zimitat, C. (2006). Understanding Taiwanese students' decision-making factors regarding Australian international higher education. International Journal of Educational Management, 20(2), 91-100.

Chung, K. C., Holdsworth, D. K., Li, Y. Q., \& Fam, K. S. (2009). Chinese "Little Emperor", cultural values and preferred communication sources for university choice. Young Consumers, 10(2), 120-132.

Cushner, K., \& Mahon, J. (2002). Overseas student teaching: Affecting personal, professional, and global competencies in an age of globalization. Journal of Studies in International Education 6(1), 44-58; DOI: 10.1177/1028315302006001004

Creswell, J. (2003). Research design. Qualitative, quantitative and mixed methods approaches (2nd ed.). Thousand Oaks, CA: Sage Publications.

Doob, L. W. (1947). The behavior of attitudes. Psychological Review, 54, 135-156.

Eder, J., Smith, W. W., \& Pitts, R. E. (2010). Exploring Factors Influencing Student Study Abroad Destination Choice. Journal of Teaching in Travel \& Tourism, 10(3), 232-250.

Juhasz, A. M., \& Walker, A. M. (1987). The impact of study abroad on university students' perceptions of self. Unpublished document. ERIC Document Reproduction Service No. ED 341916.

Gatfield, R. L., \& Hyde, M. (2005). An examination of two case studies used in building a decision - making model. International Education Journal, 555-566.
Gatfield, T. (1997). International marketing of Australian higher education to Asia: A comparative study of Australian and Asian student perceptions of quality and its implications for the Praxis of Educators, Policy Makers and Marketing Practitioners. Brisbane: Griffith University Press.

Hair, J. F., Black, W. C., Babin, B. J., Anderson, R. E., \& Tatham, R. L. (2006). Multivariate data analysis (Vol. 6). Upper Saddle River, NJ: Pearson Prentice Hall.

Hayes, A. F. (2009). Beyond Baron and Kenny: Statistical mediation analysis in the new millennium. Communication Monographs, 76(4), 408-420.

Kuh, G. K., \& Kauffman, N. F. (1984). The impact of study abroad on personal development of college students. Bloomington, IN: Indiana University School of Education.

Kauffman, J. M. (1992). The effects of the sociopolitical environment on developments in special education. Keynote presentation at the Australian Association of Special Education Conference, Perth, Western Australia.

Soo, K., \& Elliott, C. (2008). Does price matter? Overseas students in UK higher education. Economics of Education Review, 29(4), 553-565.

Lee, J. J. (2007). Beyond borders: International student pathways to the United. Journal of Studies in International Education, 12(3), 308-327 DOI: 10.1177/1028315307299418

Mazzarol, T, \& Soutar, G. N. (2002). “Push-pull” factors influencing international student destination choice. International Journal of Educational Management 16(2), 82-90.

Mahbubur Rahman, S. M., Shahin Mia, M. D., Ahmed, F., Thongrak, S., \& Kiatpathomchai, S. (2020). Assessing students' satisfaction in public universities in Bangladesh: An empirical study. Journal of Asian Finance, Economics and Business, 7(8), 323-332. https://doi.org/10.13106/jafeb.2020.vol7.no8.323

Li, M. (2015). Mainland Chinese students in Hong Kong and Macau. International Higher Education, 46. https://doi. org/10.6017/ihe.2007.46.7944

Nash, D. (1976). The personal consequences of a year of study abroad. Journal of Higher Education, 47(2), 191-203.

Nunnally, J. C (1978). Psychometric Theory. New York, NY: McGraw-Hill.

Nurosis, M. J. (1993). SPSS Statistical Data Analysis SPSS inc.

Pimpa, N. (2003). The Influence of Family on Thai Students' Choice Of International Education. International Journal of Educational Management, 17, 211-219.

Stephenson, S. (1999). Study abroad as a transformational experience and its effect upon study abroad students and host nationals in Santiago, Chile. Frontiers: The Interdisciplinary Journal of Study Abroad, 5. Retrieved December 3, 2005, from http://www. frontiersjournal.com/issues/vol5/vol5-01_Stephenson.pdf

Rosenberg, M. J. \& Hovland, C. I. (1960). Cognitive, affective and behavioral components of attitudes. In: C. I. Hovland \& M. J. Rosenberg (Eds), Attitude Organization and Change (pp. 1-14). New Haven, CT: Yale University Press. 
Tran, V. D. (2020). Assessing the effects of service quality, experience value, relationship quality on behavioral intentions. Journal of Asian Finance, Economics and Business, 7(3), 167-175.https://doi.org/10.13106/jafeb.2020. vol7.no3.167

Trisnaningsih, S., Sutrisno, S., Permatasari, Y., Hendra, F. H., \& Sulistyowati, E. (2020). Contingency model to increase the uptake of Higher Education graduates in the job market. Journal of Asian Finance, Economics and Business, 7(4), 197-203. https://doi.org/10.13106/jafeb.2020.vol7. no4.197

Teichler, U. (2004). Temporary study abroad: The life of Erasmus students. European Journal of Education, 39(4), 395-408.
Yang, M. (2007). What attracts mainland Chinese students to Australian higher education? Studies in Learning Evaluation, Innovation and Development,4(2) 1-12.

Wicker, A. W., \& Pomazal, R. J. (1971). The relationship between attitudes and behavior as a function of specificity of attitude object and presence of a significant person during assessment conditions. Representative Research in Social Psychology, 2(2), 26-31.

Wilson, S. C., \& Barber, T. X. (1983). The fantasy-prone personality: Implications for understanding imagery, hypnosis and parapsychological phenomena. In: A. A. Sheikh (Ed.). Imagery: Current theory, research and application (pp. 340390). New York, NY: Wiley. 